\title{
PENGELOLAAN LIMBAH B3 FASILITAS PELAYANAN KESEHATAN (MEDIS PADAT) DI PUSKESMAS $X$
}

\author{
Masruddin $^{1}$, Beny Yulianto ${ }^{2}$, Surahma Asti Mulasari ${ }^{3}$, Suci Indah Sari ${ }^{4}$ \\ ${ }^{1}$ Program Pasca Sarjana Kesehatan Masyarakat, Universitas Ahmad Dahlan, Yogyakarta \\ ${ }^{2 \& 4}$ STIKes Hang Tuah Pekanbaru \\ ${ }^{3}$ Universitas Ahmad Dahlan, Yogyakarta \\ masrudin076@gmail.com¹beny_ny86@htp.ac.id ${ }^{2}$
}

\begin{abstract}
Public Health Center is a health service institusi that organizes public health efforts that prioritize efforts to promote and preventive services. Waste is unused material which has a negative impact on the community if it is not managed properly. The purpose of the study was to find out Management of medical waste at XIII Koto Kampar X Health Center. This type of research is qualitative with survey design. This research was conducted during April-Juny. The subjects in this study were the Head of the Community Health Center, the Environmental Health Sanitation Section, and Cleaning Service. The instrument used in this study is direct observation or observation using a checklist sheet and indepth interview method. The volume of medical waste for 3 months is $6.5 \mathrm{~kg}$. The status of the management of medical waste in the XIII Koto Kampar X Health Center is still not referring to the RI / No.56 / 2015 Minister of Environment and Forestry Regulation, because the Community Health Center is still manually burning the waste produced. It is recommended for the XIII Koto Kampar X Public Health Center to be able to carry out solid medical waste management in accordance with RI / No.56 / 2015 Minister of Environment and Forestry Regulation.
\end{abstract}

Keyword $\quad$ : Medical Waste (Mw), Management Waste, Public Health Center

\begin{abstract}
ABSTRAK
Pusat Kesehatan Masyarakat (Puskesmas) merupakan instalasi pelayanan kesehatan yang menyelenggarakan upaya kesehatan masyarakat yang lebih mengutamakan upaya pelayanan promotif dan preventif. Limbah adalah bahan buangan dan tidak terpakai yang berdampak negatif terhadap masyarakat jika tidak dikelola dengan baik. Tujuan penelitian yaitu untuk mengetahui Pengelolaan Limbah B3 (medis padat) di Puskesmas XIII Koto Kampar X. Jenis penelitian ini adalah kualitatif dengan desain survei. Penelitian ini dilakukan selama bulan April-Juni 2020. Subjek dalam penelitian ini yaitu Kepala Puskesmas, Bagian Sanitasi Kesehatan Lingkungan, dan Cleaning Service. Instrument yang digunakan dalam penelitian ini yaitu observasi atau pengamatan langsung dengan menggunakan lembar checklist dan metode wawancara mendalam. Volume limbah medis selama 3 bulan yaitu $6,5 \mathrm{~kg}$. Status pengelolaan limbah medis di Puskesmas XIII Koto Kampar X ini masih belum mengacu kepada Peraturan Menteri Lingkungan Hidup dan Kehutanan RI/No.56/2015, karena pihak Puskesmas masih melakukan pembakaran manual terhadap limbah yang dihasilkan. Disarankan bagi pihak Puskesmas XIII Koto Kampar X agar dapat melakukan pengelolaan limbah medis padat mengacu kepada Peraturan Menteri Lingkungan Hidup dan Kehutanan RI/No.56/2015.
\end{abstract}

Kata Kunci : Limbah Medis (B3), Pengelolaan Limbah, Puskesmas

\section{PENDAHULUAN}

Limbah padat yang dihasilkan oleh Puskesmas berdasarkan karakteristik dan ketentuan pengelolaannya secara garis besar dibagi menjadi dua bagaian yaitu limbah padat medis (selanjutnya disebut limbah B3) dan limbah padat non medis (domestik). Dalam rangka mencapai fungsi Puskesmas yang ramah dengan permasalahan kesehatan lingkungan, salah satu standar dan persyaratan kesehatan lingkungan Puskesmas sesuai dengan Keputusan Menteri Kesehatan Repubik Indonesia No.1428/MENKES/SK/XII/2006 setiap Puskesmas harus memiliki sarana 
dan fasilitas sanitasi diantaranya pengelolaan limbah medis pada (limbah B3).

Limbah medis padat yang berasal dari Puskesmas harus dikelola sebagai berikut sampah infeksius harus dipisahkan dengan sampah non infeksius, setiap ruangan harus disediakan tempat sampah dari bahan yang kuat, bahan yang cukup ringan, tahan karat, kedap air, dan mudah dibersihkan serta dilengkapi dengan kantong plastik. Warna kantong plastik tersebut harus dibedakan untuk setiap jenis limbah infeksius menggunakan plastik berwarna kuning, benda-benda tajam dan jarum ditampung pada wadah khusus seperti botol sebelum dimasukan ke kantong plastik, sampah infeksius dimusnahkan di dalam incinerator (Nursamsi et al, 2017).

Dampak dari limbah medis yang tidak dikelola dengan baik terhadap lingkungan yaitu dapat menyebarkan kuman penyakit dan berkembang di lingkungan sarana kesehatan, melalui udara, air, lantai, makanan dan benda-benda peralatan medis maupun non medis. Dari lingkungan, kuman dapat sampai ke tenaga kerja dan penderita baru. Sedangkan dampak limbah medis yang tidak dikelola dengan baik terhadap pekerja yaitu terjadinya kecerobohan kerja seperti tertusuk oleh limbah jarum suntik, terkena cairan berbahan kimia, dan berbagai macam mikriorganisme pathogen yang terdapat pada limbah sehingga menyebabkan terjadinya penularan penyakit terhadap yang terpajan (Rahno, et al, 2015).

Apabila Puskesmas tidak memiliki incinerator, maka limbah medis harus disimpan di TPS khusus dan segera diangkut dalam waktu tidak lebih dari 24 jam ke pengelolaan limbah medis yang berizin melalui kerja sama, dengan transportir berizin atau ke fasilitas pelayanan kesehatan lainnya yang memiliki incinerator dan mempunyai surat izin untuk menerima dan mengolah limbah medis dari tempat lain. Dimana pengangkutan dapat menggunakan kendaraan roda tiga dengan box tertutup yang dilengkapi dengan simbol-simbol limbah B3 serta persyaratan lainnya yang telah ditetapkan. Hal ini disebabkan oleh kandungan yang terdapat dalam limbah tersebut bersifat infeksius, toksik dan radioaktif. Limbah pelayanan kesehatan tersebut apabila terjangkau oleh binatang pengganggu atau serangga seperti lalat, kecoa, tikus dan lain-lain dapat menularkan penyakit (Depkes RI, 2004).

Di Kecamatan XIII Koto Kampar terdapat 3 Puskesmas, tetapi peneliti hanya melakukan penelitian terhadap 1 Puskesmas diantara ke 3 Puskesmas tersebut. Berdasarkan hasil survei awal yang peneliti lakukan seluruh Puskesmas tersebut sudah melakukan kerja sama dalam pengelolaan limbah medis padat yang dihasilkan. Kerja sama tersebut adalah dengan mengumpulkan limbah medis padat di Puskesmas XIII Koto Kampar X karena di Puskesmas tersebut sudah memiliki alat untuk membakar limbah medis padat yaitu incinerator. Namun karena beberapa kendala, menyebabkan pihak Puskesmas hanya mengumpulkan limbah medis padat yang dihasilkan di bagian belakang bangunan Puskesmas di tempat terbuka kemudian membakar limbah tersebut. Kendala Puskesmas XIII Koto Kampar X tidak melakukan pengangkutan limbah untuk pengelolaan menggunakan incinerator karena jumlah limbah medis yang dihasilkan hanya $6,5 \mathrm{~kg} / 3$ bulan tidak sebanding dengan biaya yang dikeluarkan untuk pengangkutan limbah tersebut.

Adapun tujuan dari penelitianini yaitu untuk mengetahui Pengelolaan Limbah B3 (medis padat) di Puskesmas XIII Koto Kampar X.

\section{METODE}

Jenis penelitian ini adalah penelitian kualitatif dengan menggunakan metode survey. Metode survey yang digunakan yaitu dengan melakukan observasi atau pengamatan langsung dengan menggunakan lembar checklist dan metode wawancara. Survey yang dilakukan yaitu mengenai Pengelolaan Limbah B3 dari 
Fasilitas Pelayanan Kesehan (Medis Padat) di Puskesmas $\mathrm{X}$ yang dilakukan terhadap Kepala Puskesmas (KP), Bagian Sanitasi Kesehatan Lingkungan (KL), dan Cleaning Service (CS).

\section{HASIL}

\section{Sumber Limbah}

Pada saat melakukan survei, peneliti melakukan wawancara mengenai sumber limbah medis "Di ruang manakah yang menjadi sumber limbah...”. Berikut hasil wawancara:

"Sumber limbah biasanya cuma dari UGD tu dari kegiatan imunisasi sama KB" (hasil wawancara dengan $K L$ ).

"Sumber limbah dari UGD, ha tapi yang paling banyaknya tu dari ruang KB sama Imunisasi lah" (hasil wawancara dari CS).

\section{Jenis Limbah}

Pada saat melakukan survei, peneliti melakukan wawancara mengenai jenis limbah "Jenis limbah apa saja yang di hasilkan di Puskesmas ini..?.”. Berikut hasil wawancara:

"ya seperti suntikan, spet, pil-pil yang sudah kadaluarsa, kasa" (hasil wawancara dengan $K L$ ).

"Suntik, infus, ya paling suntikan lah yang paling banyak" (hasil wawancara dengan $C S)$.

\section{Volume Limbah}

Pada saat melakukan survei, peneliti melakukan wawancara mengenai volume limbah "berapa banyak volume atau jumlah limbah yang dihasilkan di Puskesmas ini...?". Berikut hasil wawancara:

"Kalau untuk jumlah limbah di puskesmas ini hanya sedikit, jadi gak pernah lah ditimbang" (hasil wawancara dengan KL).

"Limbahnya gak pernah saya timbang jadi gak tau lah berapa jumlahnya" (hasil wawancara dengan CS).

Tahap Pemilahan Limbah
Dari hasil wawancara yang dilakukan dilapangan diperoleh bahwa dalam proses pemilahan antara limbah medis dan non medis sudah dilakukan pemilahan disetiap ruangan sesuai dengan penempatan dan jenisnya. "bagaimana pemilahan limbah medis di Puskesmas ini, apakah sudah melakukan pemilahan di setiap ruangan...?". Berikut hasil wawancara:

"Kalau pemilahan limbah sebelumnya kita kan udah ada tempat sampahnya, kalau semacam spet, pil-pil, semacam kasa dan sampah-sampah plastik biasa ada pula lah tempatnya terpisahkan, disetiap ruangan pun udah kita siapkan tempatnya masingmasing" (hasil wawancara dengan KL).

"Pemilahan sampahnya ada disetiap ruangan dikasih 2 tempat sampah, kalau untuk sampah suntikan-suntikan, botol obat, sama kasa tu di kotak kuning yang dari kardus tu tempatnya, tapi kalau untuk sampah biasa yang kayak plastik-plastik tu lah kan di tempat sampah yang biasa dari plastik tu tempatnya" (hasil wawancara dengan $C S$ ).

\section{Tahap Pengumpulan Limbah}

Pada tahap pengumpulan, limbah yang dihasilkan dari tindakan pelayanan terhadap pasien dikumpulkan dalam box kuning yang berlabel lalu dikumpulkan dalam suatu ruangan kecil khusus limbah medis "bagaimana tahap pengumpulan limbah medis di Puskesmas ini...?". Berikut hasil wawancara:

"Pengumpulan limbahnya itu nanti di kotak kuning yang kardus itu baru nanti di masukkan kedalam ruangan kecil yang ada dibawah tangga bagian belakang Puskesmas, nah disanalah dikumpulkan semua limbahnya yang kayak jarum suntik tadi tu" (hasil wawancara dengan KL).

"Ya pagi-pagi tu tiap mau nyapukan dikumpulkan sampahnya tu dulu, yang sampah medis ya sama sampah medis pula, yang sampah plastik-plastik tu ya disamakan pula, jadi gak dicampurlah. Kayak sampah medis tu nanti diletakkan di dalam ruangan kecil pas dibawah tangga, 
ruangannya tu dikunci" (hasil wawancara dengan $(S)$.

\section{Tahap Pengangkutan Limbah}

Pada tahap pengangkutan, limbah yang diangkut hanya menggunakan tangan yaitu mengangkat langsung limbah yang dihasilkan bersamaan dengan tempatnya menuju tempat penampungan. Frekuensi pengangkutan limbah medis tergantung banyaknya limbah yang dihasilkan di setiap ruangan biasanya dilakukan 1 kali 2 hari "Untuk pengangkutan limbah medisnya itu dilakukan berapa kali perharinya, dan menggunakan apa pengangkutannya...?" Berikut hasil wawancara:

"Untuk pengangkutan limbahnya itu diangkut sama cleaning service kadang 1 kali 2 hari kadang 1 kali 1 hari tergantung keadaan limbahnyalah, terus limbahnya itu diangkut ke tempat penyimpanannya di bawah tangga" (hasil wawancara dengan $K L)$.

"Pengangkutan itu biasanya saya 1 kali 2 hari karna kondisi sampahnya kering, kadang 1 kali 1 hari kalau kondisi sampahnya basah. Ngangkatnya pun saya ya seperti biasa cuma pakai sarung tangan ngangkat tempat sampahnya itu ke tempat penyimpanannya" (hasil wawancara dengan $C S$ ).

\section{Tahap Pengolahan Limbah}

Pada tahap pengolahan, limbah yang dihasilkan hanya diolah sendiri oleh petugas cleaning service di area sekitar belakang Puskesmas "bagaimana pengolahan limbah medis di Puskesmas ini...?". Berikut hasil wawancara:

"Kalau untuk limbah medis tu pengolahannya sampai saat ini ya masih di bakar sendiri sama cleaning service nya di belakang tu dicampur aja limbahnya semua, dulu dibelakang tu dibuat lobang untuk tempat bakarnya, cuma karna udah penuh lah lobang tu kan akhirnya datar aja lagi nampaknya. Sebenarnya kami udah ada juga kerja sama dengan pihak ketiga sama Puskesmas di Batu Bersurat tapi kami gak ngantarin kesana karna biaya yang dikeluarkan tadi gak sebanding sama banyak limbahnya" (hasil wawancara dengan $K L$ ).

"Pengolahannya ya setelah saya kumpulkan limbah tadi tu kan baru saya bakar biasa aja lagi dibelakang sana, setelah saya bakar itu habis lah semua limbahnya, kecuali kayak botol-botol kaca tu gak hancur dia" (hasil wawancara dengan $C S$ ).

\section{Sumber Daya Manusia (SDM)}

Pada saat melakukan survei, peneliti melakukan wawancara mengenai Sumber Daya Manusia khususnya yang bertanggung jawab dalam pengelolaan limbah medis di Puskesmas "bagaimana sumber daya manusia di puskesmas ini, apakah sudah sesuai...?". Berikut hasil wawancara:

"Petugas untuk pengelolaan limbah ini ya sebenarnya kan memang harusnya dari kesmas atau lebih bagusnya dari kesling, tetapi disini petugas sanitasi kesehatan lingkungan kami masih dari lulusan perawat, jadi ya menurut saya ini masih belum sesuai dengan yang seharusnya, yang nantinya akan kami benahi" (hasil wawancara dengan KP).

"SDM disini untuk pengelolaan limbah menurut saya sudah sesuailah karna limbah yang dihasilkan pun hanya sedikit, jadi tidak perlu banyak orang untuk mengelolanya" (hasil wawancara dengan $K L)$.

"Dalam mengelola sampah-sampah ni lah kan ya Cuma saya sendiri yang ngolahnya" (hasil wawancara dengan CS)

\section{Standar Operasional Prosedur (SOP)}

Pada saat melakukan survei, peneliti melakukan wawancara mengenai Standar Operasional Prosedur (SOP), Puskesmas masih belum memiliki SOP dalam pelaksanaan pengelolaan limbah medisnya "apakah di Puskesmas ini sudah memiliki SOP dalam pelaksanaan pengolahan limbahnya...?". Berikut hasil wawancara:

"Masalah SOP kita belum ada, kita masih menjalankan pengolahan yang seadanya 
untuk saat ini" (hasil wawancara dengan $K P)$.

"Untuk saat ini kita masih belum punya SOP dalam pengolahannya, kita masih melakukaan pengolahan ya seperti biasa saja tanpa ada mengikuti aturan-aturan yang baku lah untuk masalah seperti itu" (hasil wawancara dengan KL).

\section{Dana Operasional}

Pada saat melakukan survei, peneliti melakukan wawancara mengenai dana operasional untuk pengelolaan limbah "adakah dana khusus dari Pemerintah untuk pengelolaan limbah di Puskesmas...?". Berikut hasil wawancara:

"Untuk dana kita masih kekurangan untuk pengelolaan limbah, dan untuk saat ini pun kami masih berusaha untuk mengajukan ke $A P B D$ " (hasil wawancara dengan KP).

"Dana untuk pengelolaan limbah ini tidak ada, kalaupun kami melakukan pengelolaan dana yang dikeluarkan murni dari Puskesmas sendiri" (hasil wawancara dengan $K L$ ).

\section{PEMBAHASAN}

\section{Volume Limbah Medis}

Berdasarkan hasil observasi dengan menggunakan lembar checklist dan wawancara bahwa Puskesmas menghasilkan volume limbah yang hanya sedikit perbulannya dan tidak pernah dilakukan penimbangan oleh pengelola limbah medis di puskesmas XIII Koto Kampar X.

Hal ini tidak sejalan dengan penelitian Febrina (2011), yaitu karena tempat penelitian febrina melakukan penimbangan limbah medis/hari. Jumlah sampah yang dihasilkan rumah sakit berasal dari karyawan, pasien rawat jalan, rawat inap, dan pengunjung. Puskesmas seharusnya melakukan penimbangan limbah medis yang dihasilkan yang nantinya jumlah atau volume limbah yang dihasilkan dapat digunakan untuk menyusun strategi pengelolaan limbah medis padat di Puskesmas tersebut.

\section{Pemilahan Limbah Medis}

Pada tahap pemilahan, sistem pemilahan dilakukan berdasarkan limbah medis dan non medis, tempat limbah medis yang disediakan yaitu safety box untuk bekas jarum suntik sedangkan untuk limbah non medis menggunakan tempat sampah berbahan plastik. Dengan proses pemilahan tersebut diharapkan adanya kategori/klasifikasi limbah yang dihasilkan oleh Puskesmas sehingga mempermudah petugas pengelolaa untuk melanjutkan ke tahap selanjutnya. Dapat diketahui bahwa tahap pemilahan limbah medis padat yang dilakukan masih belum sesuai menurut PerMenLHK Nomor:P.56/MenLHKSetjen/2015, yaitu proses pemilahan dilakukan dari sumber serta dipisahkan antara limbah medis dan non medis. Berdasarkan Permenkes RI 1204/MENKES/SK/X/2004 seharusnya limbah Puskesmas dipisahkan menurut limbah infeksius, patologi, farmasi, benda tajam, sitotoksis. Pemilahan limbah harus dilakukan dari sumber, jumlah, dan jenis yang menghasilkan limbah dan dipisahkan antara limbah medis dan non medis.

Hal yang sama disebutkan dalam hasil penelitian Yulianto (2014) yaitu tahap pemilahan limbah medis padat Puskesmas se-kota Pekanbaru, menunjukkan bahwa Puskesmas telah melakukan proses pemilahan berdasarkan tempat sampah medis dan non medis, semua tempat sampah diberi label, sehingga petugas sudah mengetahui untuk membuang sampah berdasarkan jenisnya. Sistem pemilahan limbah yang baik akan mempermudah proses berikutnya. Setiap ruangan harus disediakan tempat sampah yang terbuat dari bahan yang kuat, cukup ringan, tahan karat, kedap air dan mudah dibersihkan serta dilengkapi dengan kantong plastik. Dan dilengkapi dengan kode warna ataupun simbol berdasarkan jenisnya.

\section{Penyimpanan Limbah Medis}

Berdasarkan hasil observasi dengan menggunakan lembar checklist dan 
wawancara pada tahap penyimpanan limbah dapat diketahui bahwa di Puskesmas XIII Koto Kampar X terdapat tempat khusus sebagai tempat penyimpanan limbah medis padat, namun tempat penyimpanan ini terlalu kecil dan temboknya tidak diplaster menggunakan semen, hanya menggunakan batu bata saja. Serta, tidak memiliki kran atau sumber air disekitar tempat penyimpanan limbah. Hal ini tidak sesuai menurut PerMenLHK Nomor : P.56/MenLHK-Setjen/2015, yaitu menyimpan limbah medis padat di fasilitas Penyimpanan limbah medis, menyimpan limbah medis padat menggunakan wadah sesuai kelompok limbah medis, penggunaan warna pada setiap kemasan dan/atau wadah limbah sesuai karakteristik limbah, pemberian simbol dan label limbah medis pada setiap kemasan dan/atau wadah limbah medis sesuai karakteristik limbah.

Banyak factor yang menyebabkan proses penyimpanan limbah B3 medis tidak berjalan dengan baik, faktor utama yang menyebabkannya ialah kurangnya perhatian terhadap kondisi kesehatanlingkungan di Puskesmas. Dalam PermenLHK No 56 Tahun 2015 mengatakan batas maksimal penyimpanan limbah b3 jika tidak memiliki fasilitas penyimpanan hanya 2(dua) hari sejak limbah itu dihasilkan Pada kondisi tersebut dari pihak Puskesmas harus menyerahkan limbah b3 medis tersebut kepada pihak lain yang memiliki izin pengelolaan limbah B3 medis. Tahapan ini yang tidak sesuai karena pihak puskesmas masih menyimpan limbah B3 terlalu lama ditempat yang tidak memenuhi syarat.

\section{Pengangkutan Limbah Medis}

Berdasarkan hasil observasi dengan menggunakan lembar checklist dan wawancara pada tahap pengangkutan limbah medis padat diketahui bahwa pada tahap pengangkutan limbah medis yang dilakukan oleh petugas cleaning service tidak sesuai menurut PerMenLHK Nomor:P.56/MenLHK-Setjen/2015, karena petugas tidak menggunakan container atau alat pengangkut limbah. dan juga tidak menggunakan Alat Pelindung Diri (APD) pada saat melakukan pengangkutan limbah medis padat. Petugas cleaning service hanya mengangkut menggunakan tangan seperti biasa dan langsung membawa limbah tersebut kebagian belakang bangunan Puskesmas.

Hal yang sama ini disebutkan dalam penelitian Rahno (2015), hasil penelitian menunjukan bahwa pengangkutan limbah dilakukan oleh cleaning service dari ruangan penghasil limbah ke tempat pembuangan di belakang puskesmas. Petugas mengangkat limbah dari tempat sampah yang ada di tiap ruangan tanpa memakai alat pelindung diri (APD) dan kereta pengangkut.

Pengangkutan limbah medis yang dilakukan oleh Petugas cleaning service seharusnya menggunakan alat pelindung diri yang lengkap yang bertujuan untuk keselamatan petugas. Seperti yang dijelaskan dalam penelitian Khumaidi (2016), pengangkutan dilakukan dengan menggunakan APD yaitu masker, penutup kepala, celemek, sepatu boot dan sarung tangan lateks. Pengangkutan dengan menggunakan wadah beroda dengan kapasitas 120-200 L, pengangkutan dijadwalkan sebanyak 2 minggu sekali. Menurut hasil penelitian Khumaidi (2016), tindakan kesehatan dan keselamatan pekerja meliputi pelatihan kerja, penyediaan alat dan pakaian, serta program kesehatan seperti imunisasi dan cek kesehatan.

\section{Pengolahan Limbah Medis}

Berdasarkan hasil observasi dengan menggunakan lembar checklist dan wawancara pada tahap pengolahan limbah medis padat dapat diketahui bahwa pengolahan limbah medis di Puskesmas XIII Koto Kampar X masih belum sesuai denganPerMenLHKNomor:P.56/MenLHK Setjen/2015,karea petugas cleaning service sebagai pengelola limbah medis di Puskesmas XIII Koto Kampar X hanya mengelola limbah yang dihasilkan secara 
manual yaitu membakar sendiri limbah yang dihasilkan di bagian belakang bangunan Puskesmas. Sebelumnya Puskesmas sudah melakukan keja sama dengan pihak ke tiga yaitu Puskesmas XIII Koto Kampar I yang sudah memiliki incinerator, akan tetapi pihak Puskesmas tidak menjalankan pengelolaan tersebut.

Dalam penelitian Rahno (2015), yang dilakukan di Puskesmas Borong hasil penelitian menunjukan bahwa pemusnahan limbah medis di Puskesmas Borong dilakukan bersamaan dengan limbah domestik lainnya, yakni dibakar tanpa menggunakan insinerator. Hal ini karena puskesmas belum memiliki insinerator dan belum ada rumah sakit di Kabupaten Manggarai Timur. Sedangkan limbah medis basah dan benda tajam yang tidak dibakar, dimasukan ke dalam lubang tertutup di belakang puskesmas.

\section{Penguburan Limbah Medis}

Berdasarkan hasil observasi dengan menggunakan lembar checklist dan wawancara pada tahap penguburan limbah medis padat dapat diketahui bahwa belum sesuai menurut PerMenLHK Nomor:P.56/MenLHK-Setjen/2015, karena petugas Puskesmas tidak melakukan penguburan terhadap sisa dari pembakaran limbah medis yang dilakukan oleh petugas cleaning service. Dulunya petugas Puskesmas sudah membuat lobang sebagai tempat pembuangan serta pembakaran limbah medis, akan tetapi lobang tersebut sudah penuh dan datar lagi dengan permukaan tanah, setelah itu Puskesmas sudah tidak lagi melakukan penggalian lobang dan sisa pembakaran hanya dibiarkan begitu saja.

Penelitian Rahno (2015) menyebutkan bahwa tempat pembakaran juga dijadikan tempat pembuangan akhir. Abu sisa pembakaran atau material sampah yang tidak terbakar dibiarkan saja di halaman belakang puskesmas. Sampah medis basah dimasukan ke dalam lubang tanpa ada pengolahan lanjutan. Hal ini berpotensi mencemari lingkungan baik internal maupun eksternal dan juga terjadinya kecelakaan (injury) bagi pekerja dan pengunjung puskesmas. Limbah infeksius yang dimasukan ke dalam lubang pembuangan akan membusuk dan menimbulkan bau yang tak sedap dan resapan limbah berpotensi mencemari tanah dan sumber air dalam tanah, serta binatang pengerat (vektor penyakit) dapat masuk ke dalam lubang dan menyebarkan penyakit.

\section{Sumber Daya Manusia (SDM)}

Berdasarkan hasil observasi dengan melakukan wawancara mendalam mengenai Sumber Daya Manusia (SDM), Puskesmas XIII Koto Kampar X memiliki tenaga bantu kesehatan lingkungan sebanyak 1 orang dan cleaning service 1 orang yang diperkirakan cukup dengan jumlah medis yang dihasilkan masih dalam volume kecil. Latar belakang tenaga bantu kesehatan lingkungan yaitu D3 keperawatan yang tidak sesuai dengan profesinya saat ini yaitu sebagai petugas kesehatan lingkungan di Puskesmas XIII Koto Kampar, sedangkan petugas cleaning service yang bertugas sebagai pengelola limbah medis merupakan lulusan SMA saja yang tidak memahami bagaimana pengelolaan limbah medis yang sesuai dengan PerMenLHK Nomor:P.56/MenLHK-Setjen/2015.

Menurut hasil penelitian Al-Azzawi (2012), menguraikan tugas dan fungsi kepala bagian pengelola limbah yakni melaksanakan upaya pengelolaan limbah, dengan selalu berkoordinasi dengan anggota tim dan seluruh civitas hospitalia guna terwujudnya pengelolaan limbah medis yang baik di rumah sakit.

Menurut hasil penelitian Sari Sari (2017), Sumber Daya Manusia atau ketenaga kerjaan dalam proses pelaksanaan pengelolaan limbah rumah sakit di RSUD Petala Bumi sudah cukup. Karena terjadi perubahan kualitas terhadap SDM di Rumah Sakit pada tahun 2017 kearah yang lebih baik. Dengan SDM yang cukup maka kinerja yang dihasilkan akan lebih baik sehingga dalam pengelolaan limbah di 
RSUD Petala Bumi akan berjalan dengan baik dan benar.

\section{Standar Operasional Prosedur (SOP)}

Standart Operasional Prosedure (SOP) dalam pengelolaan sampah medis berisi tentang pengertian, jenis dan contoh sampah medis, serta tujuan dari pembuatan SOP, kebijakan kepala puskesmas, referensi peraturan mengenai pengelolaan sampah medis, prosedur yang harus sesuai dengan

PerMenLHK

Nomor:P.56/MenLHK-Setjen/2015. Dari hasil observasi dengan melakukan wawancara mendalam mengenai Standar Operasional Prosedur (SOP), Puskesmas XIII Koto Kampar X masih belum memiliki Standar Operasional Prosedur (SOP) dalam pelaksanaan pengelolaan limbah medisnya.

Menurut hasil penelitian Arislan (2018), yaitu di puskesmas perawatan Kabupaten Merangin, didapatkan bahwa hanya 20\% Puskesmas Perawatan yang mempunyai standar operasional Prosedure (SOP) dalam pengelolaan sampah medis yaitu Puskesmas Muara Madras dan Puskesmas Pamenang. SOP pengelolaan sampah medis di Puskesmas Muara Madras sudah dijalankan, namun hanya dalam penangganan akhirnya belum menggunakan alat incinerator dikarenakan belum memiliki alat tersebut. Dan di Puskesmas Pamenang sudah ada SOP tentang pengelolaan sampah medis namun belum dijalankan dan baru dibuat serta belum memberitahukan SOP tersebut kepada kepala puskesmas. Sedangkan $80 \%$ Puskesmas Perawatan di Kabupaten Merangin belum mempunyai SOP tentang pengelolaan sampah medis dikarenakan belum ada kesadaran untuk membuatnya.

\section{Dana Operasional}

Berdasarkan hasil observasi dengan melakukan wawancara mendalam mengenai Dana Operasional untuk pengelolaan limbah medis di Puskesmas XIII Koto Kampar X tidak ada dana khusus dari Pemerintah ataupun sektor swasta.
Seluruh biaya untuk pengelolaan limbah medis murni hanya ditanggung oleh pihak Puskesmas sendiri.

Menurut hasil penelitian Khumaidi (2016), Pembiayaan Untuk Pengolahan Limbah Medis Padat Setiap Puskesmas. Puskesmas I Sokaraja. Pendanana untuk pengolahan sampah medis padat yang ada pada puskesmas sebesar Rp.2.000.000 / tahun. Belum sama pendaan alat pelindung diri Puskesmas I Cilongok.Pendanaan untuk pengolahan limbah medis padat di puskesmas pertahunya sebesar $\mathrm{Rp}$ 2.300.000. untuk sampah medis padat belum dengan alat pelindung dirinya.

\section{KESIMPULAN}

Pengelolaan limbah B3 fasilitas pelayanan kesehatan di Puskesmas XIII Koto Kampar kota Pekanbaru telah dilakukan mulai dari tahap pemilahan, penampungan dan pengangkutan, namun pada tahap pengolahan atau pemusnahan masih kurang sesuai dengan acuan PerMenLHK Nomor:P.56/MenlhkSetjen/2015. Sumber dan jenis limbah medis padat yang dihasilkan di Puskesmas XIII Koto Kampar X berasal dari UGD, Poli KIA/KB/Imunisasi, dan Poli gigi. Tanpa menghitung volume limbah perharinya. Sumber Daya Manusia (SDM) di bagian sanitasi kesehatan lingkungan yang masih belum sesuai dengan basicnya yaitu D3 Keperawatan, sehingga menyebabkan petugas kurang memahami mengenai bagaimana pengelolaan limbah medis yang sesuai berdasarkan PerMenLHK Nomor: P.56/MenlhkSetjen/2015.

\section{UCAPAN TERIMAKASIH}

Terimakasih saya ucapkan kepada Kepala Puskesmas XIII Koto Kampar, bagian Sanitasi Kesehatan Lingkungan (KL), dan Cleaning Service (CS). yang telah banyak membantu dalam penelitian ini. 


\section{DAFTAR PUSTAKA}

Al-Azzawi, S. A. (2012) 'Hospital Waste and Cleaning Workers in Baquba Teaching Hospital', Diyala Journal of Medicine, 2(1), pp. 79-83.

Arislan (2018) 'Analisis Pengelolaan Keselamatan Pasien Rumah Sakit Di Rumah Sakit Daerah Kolonel Abundjani Bangko Kabupaten Merangin Tahun 2017', Stikes merangin jurnal kesehatan dan sains terapan, 4(May 2017), pp. 29-34.

Depkes RI, 2004. Kepmenkes RI No.1204/Menkes/SK/X/2004 Tentang Persyaratan Kesehatan Lingkungan Rumah Sakit, Jakarta: Depkes RI.

Febrina, R. (2011). Sistem Pengelolaan Sampah Padat di Rumah Sakit X Jakarta Tahun 2011.

Khumaidi, I., Subagiyo, A. and Widiyanto, T. (2016) 'Analisis Pengolahan Limbah Medis Padat Pada 2 (Dua) Puskesmas Rawat Inap Dan 2 (Dua) Puskesmas Non Rawat Inap Di Kabupaten Banyumas Tahun 2016', Buletin Keslingmas, 35(4), pp. 389396.

Leonita, E. and Yulianto, B. (2014) 'Pengelolaan Limbah Medis Padat Puskesmas Se-Kota Pekanbaru', Jurnal Kesehatan Komunitas, 2(4), pp. 128-162.
Nila Puspita Sari, E. E. (2017) 'Kinerja Petugas Pengelola Limbah Rumah Sakit Di Rsud Petala Bumi Tahun 2017', Jurnal Penelitian dan Kajian Ilmiah, XI(74), pp. 20-25.

Nursamsi, N., Thamrin, T. and Efizon, D. (2017) 'Analisis Pengelolaan Limbah Medis Padat Puskesmas Di Kabupaten Siak', Dinamika Lingkungan Indonesia, 4(2), p. 86.

Nuryati, N., Mesrina C. (2019) 'Tinjauan Pemenuhan Elemen Penilaian Manajemen Informasi Dan Rekam Medis 11 Standar Nasional Akreditasi Rumah Sakit Edisi', jurnal penelitian dan kajian ilmiah kesehatan, 5(34), pp. 1-9.

Pratiwi, D. (2013). Pengelolaan Limbah Medis Padat di Puskesmas Kabupaten Pati. Jurnal Kesehatan Masyarakat. Vol. 9 No.1.

Rahno, D., Roebijoso, J. and Leksono, A. S. (2015) 'Pengelolaan Limbah Medis Padat di Puskesmas Borong Kabupaten Manggarai Timur Propinsi Nusa Tenggara Timur', Jurnsal Pembangunan dan Alam Lestari, 6(1), pp. 22-32.

Suja, P. S., Reshmi, C. R., Sagitha, P., \& Sujith, A. (2017). Electrospun nanofibrous membranes for water purification. Polymer reviews, 57(3), 467-504. 